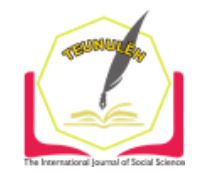

Jurnal Ilmiah Teunuleh

The International Journal of Social Sciences

Vol. 1, Issue. 1, Sept 2020

E-ISSN: 2746-4393

\title{
ANALYSIS OF TEACHER READINESS IN APPLYING THE 2013 CURRICULUM IN THE IV GRADE OF PRIMARY SCHOOL
}

\author{
Saibaton ${ }^{1}$ \\ STKIP Bina Bangsa Meulaboh \\ Email:saibaton@gmail.com \\ Mardhatillah ${ }^{2}$ \\ STKIP Bina Bangsa Meulaboh \\ Email: Mardhatillah.atjeh@gmail.com
}

\begin{abstract}
This study aims to analyze how readiness the teachers are in implementing the 2013 curriculum at SD Negeri Peureumeu, Kaway XVI District. The research approach used in this research is qualitative research. This type of research is descriptive (descriptive research). The subjects in this study were 8 teachers in Peureumeu Public Elementary School, Kaway XVI sub-district and 1 grade IV teacher was studied. Data collection methods in this research are observation, interview, documentation and validation. The conclusion of this research is that in implementing the 2013 curriculum, the fourth grade teachers at Peureumeu Public Elementary School, Kaway XVI District are very ready to implement the 2013 curriculum. The main readiness carried out by grade IV teachers at SD Negeri Peureumeu, Kaway XVI District in implementing the 2013 curriculum is the process learning, by designing or designing specifically the learning material with reference to the syllabus and lesson plans. The second is the readiness of the classroom management aspects, the three readiness methods, the fourth readiness for the use of teacher books and student books, and the last is the readiness of the assessment process, the teacher is able to use the results of the assessment analysis in the learning process, and the teacher evaluates the effectiveness of the process and learning outcomes and uses information on results assessment and evaluation to design remedial and enrichment programs.
\end{abstract}

Keywords: Teacher Readiness, Curriculum 2013 


\section{A. Introduction}

Education in school is basically an educational process that is formally organized based on a hierarchical and chronological structure, from kindergarten to tertiary level. In addition to referring to the implementation that is implemented in stages, the ongoing process of education in schools is very dependent on the existence of other subsystems consisting of students (students or students), school management, structure and timetable for teaching and learning activities, teaching materials or materials. which is arranged in a set of systems called the curriculum (Yusanto, 2014: 67).

Today there are growing demands for changes in the educational curriculum that prioritizes the need to build national character and also guides students to be positive about everything for the good of their own future. This is based on facts and people's perceptions about the decline in the quality of attitudes and morals of children or young people. What is needed now is an educational curriculum that has character in the sense that the curriculum itself has character, as well as being oriented towards the character building of students (Muhammad Rohman, 2012: 1).

The curriculum is an essential thing in an educational organization. In simple terms, the curriculum can be understood as a collection or list of lessons that will be taught to students completely by giving learning achievement values over a certain period of time. The curriculum must be able to accommodate the needs of different students individually, both in terms of time and learning ability. Therefore, formulating a curriculum is certainly not an easy matter. Many factors determine the process of creating a curriculum (Qomariyah, 2014: 21). The curriculum is one of the important things in the Indonesian education system. The purpose of compiling the curriculum is to realize the goals of the education system effectively, efficiently and effectively (Mulyasa, 2013: 6). However, the change in the Education Unit Level Curriculum (KTSP) to the 2013 Curriculum invited pros and cons from various parties. Those who do not agree with the change in the curriculum, because the changes are too hasty. On the other hand, those who support curriculum change consider these changes to meet the challenges of the times (Anzar, S. F., \& Mardhatillah, M. (2018).

The National Education System (2012: 54) states that in determining the success there are two major factors in the successful implementation of the 2013 Curriculum, the first determining factor is the suitability of the competence of educators and education personnel with the curriculum and textbooks. The second determining factor is the supporting factor which consists of three elements, namely the availability of 
books as teaching materials and learning resources that are integrated with curriculumforming standards, strengthening the role of government in coaching and supervision, and strengthening school management and culture (Mardhatillah, et al, 2019). The 2013 curriculum requires teachers to carry out learning activities based on thematic integrative and scientific approaches. However, the 2013 Curriculum will be difficult to implement in various regions due to teacher unpreparedness.

Teachers play an important role in the successful implementation of the curriculum. The teacher will ultimately implement this curriculum in the classroom. Teachers are required to improve their abilities / competencies in carrying out their duties. The abilities that must be mastered by the teacher in implementing the curriculum include understanding the essence of the goals to be achieved in the curriculum, the ability to describe general curriculum goals into more specific goals, the ability to translate specific goals into learning activities. Concepts or concept applications need to be translated into learning activities, learning methods or developing the ability to apply concepts (Yusanto, 2014: 3)

The teacher and the curriculum are two aspects of education that greatly determine the success of education itself. An education that is implemented anywhere will never achieve optimal or good results without a good teacher and curriculum. In this case a good teacher is a professional teacher as a condition for the implementation of a good educational process. Meanwhile, a good curriculum is a curriculum that can help students digest / understand subjects to foster mutual respect and tolerance for the achievement of national education.

Based on the results of an interview on April 7, 2019 with a teacher who was conducted by a researcher at SD Negeri Peureumeu, Kaway XVI District, there were several problems faced in implementing the 2013 curriculum because of several factors as follows, 1) The problem that arises is the lack of readiness teachers in implementing the 2013 curriculum because most of the teachers have not received training and socialization about the 2013 curriculum, namely 5 teachers or $(62.5 \%)$ of 8 teachers, 2) The difficulty of changing the teacher's mindset, 3) Changing the process learning from teacher centered to student centered, 4) The low culture of reading and research is still low, 5) Lack of mastery of IT by teachers, 6) Weak mastery of administration, 7) The tendency of teachers to emphasize more cognitive aspects. In fact, teachers should also give the same portion to the affective and psychomotor aspects. 8) There are still many teachers who do not want to be human learners. In fact, a teacher is required to 


\section{Saibaton; Mardhatillah}

continue to increase knowledge and broaden their horizons, especially after the implementation of the 2013 curriculum.

Therefore, teachers are expected to be more creative in carrying out learning activities, so that they are able to become facilitators and learning partners for students. In the world of education the role of the teacher is very important, because in addition to the role of transferring knowledge to students, teachers are also required to provide good education, educate, and be a good example. Teachers are professional educators with the main task of educating, teaching, guiding, directing, training, assessing, and evaluating students in early childhood education through formal education, basic education, and secondary education (Article 1 paragraph 1 of Law Number 14 of 2005 ). This means that teachers have various kinds of competencies and intelligence that clearly emanate from their character and daily behavior, both when as educators, in the professional community, and as members of society. To find out the determining factors for the success of the 2013 curriculum, especially the readiness of teachers to implement the 2013 curriculum in learning.

Based on the description above, the researcher is interested in conducting a study with the title "Analysis of Teacher Readiness in Implementing the 2013 Curriculum in Peureumeu Public Elementary Schools, Kaway XVI District".

\section{B. Method}

The research approach used in this research is qualitative research. What is meant by qualitative research is research that intends to understand the phenomena experienced by research subjects holistically and by means of descriptions in the form of words and language, in a special natural context and by utilizing various scientific methods (Moloeng, 2010). : 6). This type of research is descriptive (descriptive research) or a study aimed at describing existing phenomena that are taking place at present or in the past.

This research was conducted at SD Negeri Peureumeu, Kaway XVI District, 2018/2019 Academic Year. The time of this research is carried out in the odd semester of July until the end of 2019.

The research subject is a generalization area consisting of: objects / subjects that have certain qualities and characteristics set by the researcher to study and then draw conclusions (Sugiyono, 2015: 117). The subjects in this study were 9 class teachers at Peureumeu Public Elementary School, Kaway XVI, and 1 grade IV teacher. 
Data collection methods according to Suharsimi Arikunto (2010: 100) "data collection methods are methods that can be used by researchers to collect data". In this research, data collection methods are used, namely:

1. Observation Method

Observation is an activity to find data that can be used to provide a conclusion or diagnosis (Herdiansyah, 2011: 131).

2. Interview Method (Interview)

Interviewing is a process of question and answer or oral dialogue between the interviewer (interviewer) and the respondent or person being interviewed (interviewee) with the aim of obtaining the information needed by the researcher (Eko Putro Widoyoko, 2013: 40).

\section{Documentation Methods}

Documents are records of events that have passed. The documentation method is a method for finding data about things or variables in the form of notes, transcripts, books, newspapers, magazines, inscriptions, meeting minutes, notes, agendas and so on (Suharsimi 2013: 54).

\section{Validation}

Validation is an act / action or something that is done legally or according to the proper rules. The meaning of valid can also mean that it has been legally authorized by law and has legal consequences or obligations (Arikunto, 2010: 156).

The research instrument in this study according to Eko Putro Widoyoko (2013:51) "the research instrument is a tool used by researchers to collect research data by taking measurements". To obtain data on teacher readiness, an instrument was developed which was a description of the indicators on the teacher readiness variable. The instruments in this study were observation sheets, interview sheets, documentation sheets and validation sheets.

Data analysis techniques according to Miles and Huberman (2011: 148):

a. Data Reduction

The data obtained from the field is quite a lot, for that reason should be noted carefully and in detail. The longer the researcher goes to the field, the more data will be, complex and complicated. For this reason, it is necessary to immediately analyze data through data reduction.

b. Data Display (Presentation of Data) 


\section{Saibaton; Mardhatillah}

After the data is reduced, the next step is to present the data. The presentation of the data in this study is a narrative text. By presenting data, it will be easier to understand what happened, plan the next work based on what has been understood.

c. Conclusion Drawing (Verification)

The third step in qualitative data analysis is drawing conclusions and verification. The initial conclusions put forward are still provisional and will change if no valid and consistent evidence is found when the researcher returns to the field to collect data, then the conclusions put forward are credible. In this qualitative research, researchers used data analysis steps including data reduction, data presentation and data verification.

\section{Finding and Discussion}

Based on the results of observations made at SD Negeri Peureumeu, Kaway XVI District, among others:

1. Planning (Planning)

In this case the teacher prepares things to do before the teaching and learning process takes place. The teacher makes a Learning Implementation Plan (RPP) and prepares everything for the later teaching and learning activities. Example of sub-themes of animals and plants in my home environment. The teacher prepares lesson plans with the aim of learning that students are able to understand and explain the animals and plants around my house. Then the learning method that will be used is inquiring minds want to know (see student knowledge). This method, educators invite students to make estimates about a question which is ultimately directed to understand the material being explained.

\section{Learning Process}

After going through the planning stage, the next is the ongoing learning process. At this stage the lesson plans that have been made are put into practice. How educators deliver and direct teaching material to students so that they understand it. Examples of animals and plants around my house, the educator carried out the lesson plans he had made. Educators use the method of inquiring minds want to know (see student knowledge). Starting learning, the educator gives a question related to the content of the material to deliver. These questions can arouse the interest of students to find out more. Educators ask students to answer these questions according to the expectations they think. After the students' suspicions are accommodated, then the educator makes a 
straight line to conclude and explain the material they will learn (Observation of the Teaching and Learning Process of the sub-themes of animals and plants around my house, on Tuesday, August 27, 2019).

\section{Class Management}

Next is the classroom management aspect, this is an important factor for achieving success in learning besides the mastery of the material by educators. Even though educators are very good at the teaching material, if the classroom management aspect is not good, it will also produce unfavorable results. In this study, researchers saw the learning process directly. As was done by the fourth grade teacher of SD Negeri Peureumeu, Kaway XVI sub-district, as the class teacher, he invited all students to have a discussion together by throwing a sudden question to the students randomly. It aims to invite students to stay focused on the learning process, but still not bored. In addition to the delivery of material, educators also link the material with real life around students.

\section{Assessment (Assessment)}

Then the last is the assessment (assessment) of the learning carried out. Reciprocity or the attitude of students after getting the theme that has been conveyed. Students' understanding will be seen, if students can at least apply it in behavior or attitude. If this is not seen, there may be something that needs to be addressed in order to achieve good learning. In the learning carried out by the teachers of the Peureumeu Public Elementary School, Kaway XVI Subdistrict, he also observed the lack of behavior outside the classroom when students were visiting the teacher's room or passing by outside the classroom. Teachers are able to carry out process assessments and learning outcomes on an ongoing basis. The teacher evaluates the effectiveness of the process and learning outcomes and uses the information from the assessment and evaluation results to design remedial and enrichment programs. The teacher is able to use the results of the assessment analysis in the learning process. The 2013 curriculum assessment is carried out by combining three aspects of knowledge, skills and attitude. Teachers are required to assess and evaluate the process and results of both cognitive, affective and psychomotor tests.

The learning process in the classroom in implementing the 2013 curriculum, namely:
a. The teacher came on time.
b. Before the lesson begins, the teacher greets.
c. The teacher leads the prayer before learning. 
d. The teacher informs and associates the themes or competencies to be studied with character values for life and religion.

e. The teacher provides feedback and reinforcement as well as motivation to students who are less or not actively participating.

f. Together with students draw a lesson conclusion.

g. Before the learning ends, the teacher makes an assessment and reflection on the activities that have been implemented consistently and in a programmed manner.

h. Teachers plan follow-up activities in the form of learning enrichment programs, counseling services, or assign assignments, both individual and group assignments according to student learning outcomes.

i. To end the activity after learning, the teacher invites students to say hamdalah as gratitude and habituation.

j. The teacher ends the lesson by giving a closing greeting (Observation of the Teaching and Learning Process on Thursday, August 29, 2019).

Based on the results of the above observations, the main readiness carried out by grade IV teachers at SD Negeri Peureumeu, Kaway XVI District in implementing the 2013 curriculum is the learning process, by designing or designing specifically the learning material by referring to the syllabus and RPP. This activity was carried out by teachers at Peureumeu Public Elementary School, Kaway XVI District with the aim that the learning material could be conveyed properly to students. Because after all, the subject matter is a major component in the learning process. Second, the readiness of the classroom management aspects, this is an important factor for achieving success in learning besides the mastery of the material by the educator. Even though educators are very good at the teaching material, if the classroom management aspect is not good, it will also produce unfavorable results. The third is method readiness, because if the method selection is right, the teaching and learning process can make students active and enthusiastic in the classroom. The fourth is the readiness to use teacher books and student books, and finally the readiness of the assessment process, the teacher is able to use the results of the assessment analysis in the learning process, and the teacher evaluates the effectiveness of the process and learning outcomes and uses information on the results of assessments and evaluations to design remedial and enrichment programs. The 2013 curriculum assessment is carried out by combining three aspects of 
Analysis of Teacher Readiness in Applying the 2013 Curriculum in the IV Grade of...

knowledge, skills and attitude. Teachers are required to assess and evaluate the process and results of both cognitive, affective and psychomotor tests.

Based on the results of interview research about the readiness of teachers in implementing the 2013 Curriculum in Class IV SD Negeri Peureumeu, Kaway XVI District, among others:

1. Respondents do not object to several government policies regarding the new curriculum, in fact teachers are very supportive of the 2013 curriculum because it makes it easier and can develop creativity for teachers and students. The preparation that I did the teacher made a Learning Implementation Plan (RPP) and prepared everything in the teaching and learning activities later. At this stage the lesson plans that have been made are put into practice.

2. For prota, prosem and syllabus, I got it from the MGMP (Subject Teacher Deliberation) from the Department, while for the lesson plan I made it independently.

3. There, I sometimes copy and paste from the lesson plans of other teachers, especially the lesson plans that often change. However, I modified it according to the current regulations, not only as long as copy and paste but still adjusted to the learning objectives to be achieved.

4. Teachers and students are ready to use books as learning material.

5. The teacher compiles the syllabus according to the most important objectives of the curriculum and uses lesson plans in accordance with the objectives and learning environment. Teachers are able to select, arrange, and organize learning materials according to the needs of students so that learning objectives are achieved.

6. The readiness of the learning process is good. Teachers are able to condition and activate their students in class.

7. The teacher evaluates the effectiveness of the process and learning outcomes and uses the information from the assessment and evaluation results to design remedial and enrichment programs. The teacher is able to use the results of the assessment analysis in the learning process.

8. My way of teaching that makes students active and enthusiastic in the classroom. The methods I use include lectures, advice, discussions, assignments, questions and answers and direct practice. 


\section{Saibaton; Mardhatillah}

9. Books on student themes and student worksheets, but students are not limited in using source books, they may use the internet and other learning resources as supporting learning resources.

10. By means of tests both in writing and orally. Sometimes also using peer assessment, how to give an assessment can be direct or wait for the finished correction results.

11. The teacher's obstacle in preparing for the 2013 curriculum learning, namely the teacher's competence in combining content and teaching it in a theme is still difficult for some teachers, teachers still find it difficult to deliver collaborative learning in themes. Teachers also have constraints in mastery of IT, lack of socialization and training regarding the development of the 2013 curriculum.

12. To overcome the obstacles, namely schools must often hold socialization and training regarding the development of the 2013 Curriculum. smart or know in IT teaching other teachers to process IT.

From this research, the teacher has understood the 2013 curriculum with a learning pattern that has moved from being teacher-centered to being studentcentered. Teacher work procedures in the 2013 curriculum are not individual but collaborative with fellow teachers. In the learning process, the teacher understands that the 2013 curriculum requires interactive learning between students and students, between students and teachers, students and the community and students with their surroundings. Learning is carried out through integrative thematic-based learning to foster students in multi-disciplinary learning. The main objective of the 2013 curriculum is to develop students' attitudes, knowledge and skills according to their respective characteristics.

According to George (2009: 22), readiness is the overall condition of a person that makes him ready to respond in a certain way to a situation. The person's condition includes 3 aspects, namely: a) physical, mental, and emotional conditions, b) needs, motivation, and goals; and c) other skills, knowledge and understanding that have been learned.

Based on the results of the above observations, the main readiness carried out by grade IV teachers at SD Negeri Peureumeu, Kaway XVI District in implementing the 2013 curriculum is the learning process, by designing or designing specifically the learning material by referring to the syllabus and RPP. This activity was carried out by teachers at Peureumeu Public Elementary School, Kaway XVI District with the aim that the learning 
material could be conveyed properly to students. Because after all, the subject matter is a major component in the learning process. Second, the readiness of the classroom management aspects, this is an important factor for achieving success in learning besides the mastery of the material by the educator. Even though educators are very good at the teaching material, if the classroom management aspect is not good, it will also produce unfavorable results. The third is method readiness, because if the method selection is right, the teaching and learning process can make students active and enthusiastic in the classroom. The fourth is the readiness to use teacher books and student books, and finally the readiness of the assessment process, the teacher is able to use the results of the assessment analysis in the learning process, and the teacher evaluates the effectiveness of the process and learning outcomes and uses information on the results of assessments and evaluations to design remedial and enrichment programs. The 2013 curriculum assessment is carried out by combining three aspects of knowledge, skills and attitude. Teachers are required to assess and evaluate the process and results of both cognitive, affective and psychomotor tests.

Based on the results of the interview, in implementing the 2013 curriculum, the fourth grade teachers of SD Negeri Peureumeu, Kaway XVI sub-district were very ready to implement the 2013 curriculum and carry out their duties as teaching staff. But they have difficulties in terms of learning media and assessment. For them, curriculum change is not a new thing. It seems that the teachers in implementing the 2013 curriculum are quite serious and they must live it as usual. First, the teacher has difficulty in assessing students, because of the many implications or assessment items such as assessing student learning attitudes, knowledge, and student religious assessments. The obstacle for teachers in preparing the 2013 curriculum, namely the competence of teachers in combining content and teaching it in themes, is still difficult for some teachers, teachers still find it difficult to deliver collaborative learning in themes. Teachers also have problems in mastering IT, because older teachers tend not to want to learn IT. Even though IT is very important for the 2013 curriculum. Another obstacle is the rotation of teachers between levels which creates problems, because teachers have to prepare new tools and administration, teachers find it difficult to adapt to the new rotation system imposed by foundations and between schools which creates separate obstacles. To overcome teachers who are still difficult to use IT, namely by training in using computers together, for example, one elementary school, so if one of the teachers already knows and is smart or knows in the field of IT, teach other teachers to process IT. 


\section{Conclusion}

From the results of research that has been conducted at the Peureumeu Public Elementary School, Kaway XVI District, it can be concluded:

1. That the readiness of the fourth grade teachers of SD Negeri Peureumeu, Kaway $\mathrm{XVI}$ sub-district is generally ready. However, teachers are constrained in preparing for the 2013 curriculum learning, namely the competence of teachers in combining content and teaching it in a theme that is still difficult for some teachers, teachers still find it difficult to deliver collaborative learning in themes. Teachers also have constraints in mastery of IT, lack of socialization and training regarding the development of the 2013 curriculum.

2. To overcome the obstacles, namely schools must often hold socialization and training regarding the development of the 2013 Curriculum. smart or know in IT teaching other teachers to process IT.

\section{Bibliography}

Anzar, S. F., \& Mardhatillah, M. (2018). Analisis Kesulitan Belajar Siswa Pada Pembelajaran Bahasa Indonesia di Kelas V SD Negeri 20 Meulaboh Kabupaten Aceh Barat Tahun Ajaran 2015/2016. Bina Gogik: Jurnal IImiah Pendidikan Guru Sekolah Dasar, 4(1).

Eko,. Putro,. Widoyoko. 2014. Teknik Penyusunan Instrumen Penelitian. Yogyakarta: Pustaka Pelajar.

George. 2012. Peningkatan Kualifikasi Guru dalam Perspektif Teknologi Pendidikan. Jurnal Pendidikan Penabur 7 (10):66-76.

Herdiansyah. 2013. Upaya Pengembangan Profesionalisme Guru di Indonesia. Jurnal Ekonomi dan Pendidikan, Vol 1 No. 4.

Mardhatillah, M., Verawati, V., Evianti, E., \& Pramuniati, I. (2019). Bahan Ajar Interaktif Berbasis Kearifan Lokal Melalui Pendekatan Saintifik Pada Pembelajaran Bahasa Inggris. Genta Mulia: Jurnal IImiah Pendidikan, 10(1).

Miles \& Huberman. 2011. Statistika untuk Penelitian. Bandung: Alfabeta.

Mulyasa. 2013. Standar Kompetensi dan Sertifikasi Guru. Bandung: Remaja Rosdakarya.

Qomariyah. 2014. Kesiapan Guru Dalam Menghadapi Implementasi Kurikulum 2013. Jurnal Pendidikan Ekonomi IKIP Veteran Semarang, Volume. 2 No. 1. Rohman, Muhammad. Dampak Implementasi Kurikulum 2013 Terhadap Guru. 
Analysis of Teacher Readiness in Applying the 2013 Curriculum in the IV Grade of...

Jurnal Pendidikan Guru Sekolah Dasar, Vol. 3, No. 19/I/P3DI/Oktober/2012. Suharsimi, Arikunto. 2011. Evaluasi Program Pendidikan. Jakarta: Bumi Aksara.

2013. Model-model Pembelajaran. Depok: PT. Raja Grafindo Persada. Sisdiknas. 2013. Materi Pelatihan Guru Implementasi Kurikulum 2013. Jakarta: Kementerian Pendidikan dan Kebudayaan.

Sugiyono. 2015. Metode Penelitian Pendidikan. Bandung: Alfabeta.

Yusanto. 2014. Menggagas Sistem Pendidikan Islam. Jakarta: Al-Azhar Press. 